\title{
PREDICTION OF RUNOFF IN THE UM-U-LAH CATCHMENT OF EXTREMELY HUMID AREA OF CHERRAPUNJI, INDIA
}

\author{
SURENDRA SINGH, HIAMBOK J. SYIEMLIEH \\ Department of Geography, North-Eastern Hill University, Shillong 793 022, India \\ E-mail: surendra_singh48@hotmail.com
}

\begin{abstract}
In the studies of runoff prediction, the Variable Source Area (VSA) methods are becoming increasingly more pronounced especially for the humid areas, such as the North-Eastern areas of India. Such methods of physically-distributed modelling system are greatly dependent on land surface characteristics (slope gradient, hydrological soil types and land use/ land cover patterns) that are stable spatially, and on the temporarily fluctuating pattern of precipitation intensity. Considering grid cells of $10 \mathrm{~m} * 10 \mathrm{~m}$ size in a micro-areal watershed of 103 ha called Um-U-Lah that is situated in the extremely humid area of Cherrapunji, having an average slope varying from 4 to 30 percent, and with sandy-loam porous soils with grass land dominating vegetal cover, the mapping of the saturated area adopting the Topographic Wetness Index (TWI) was made to measure the location and extent of saturated areas, which contract and expand in proportion to the changes in intensity of effective rainfall. After calibrating the Curve-Number based VSA model at effective available soil storage of $5.88 \mathrm{~mm}$ (AMC-III Soil conditions) and at Initial Abstraction of $1.746 \mathrm{~mm}$, the rainfall simulation were conducted. It is found that increasing depth of effective rainfall quickly expands the saturated areas over the flat lands of hill-tops and slopes in the watershed. At $8.25 \mathrm{~mm}$ of effective rainfall depth, about 85.03 percent areas of watershed becomes saturated directly contributing to runoff.
\end{abstract}

Key words: runoff process, extremely humid area, variable source area and topographic wetness index

\section{INTRODUCTION}

There are numerous studies on the runoff processes operating in most humid areas, such as the North-Eastern part of India, where runoff is generated either by direct precipitation and/or by exfiltration from saturated areas near stream channels (Beven and Kirkby, 1979; Ward, 1984; Singh and Syiemlieh, 2010). Of course, hydrological processes are governed by the atmospheric water circulation and land surface characteristics of a river catchment. Rainfall, evaporative demand of atmosphere, soil water retention capacity, topographical and land use/land cover patterns are major attributes controlling the runoff. As topographic attributes (soil types, slope gradients and land use/land cover patterns) are spatially stable and patterns of precipitation intensity are temporally fluctuating, the modelling for the prediction of runoff in such areas of high rainfall may be associated with the analysis of dynamics of saturated areas, which are largely dependent on the above cited topographic features of any river catchment. As a result, these saturated areas are referred to as the Variable Source Area (VSA). A pioneering work of this kind started as VSA - hydrology by the scientists at Cornell 
University, Ithaca, USA, with several studies on the Soil Moisture Distribution Model (SMDR 2003), GIS-based variable source area (Frankenberger et al., 1999), and physically based hydrological model (Bevan and Kirkby, 1979; Mishra et al., 2008).

There are many issues addressed by the scientists using runoff modelling in environmental impact assessment, non-point pollutant assessment, and land degradation problems for the best land management practices, proposing better land use pattern, optimal hydrograph, optimal soil nutrient status and good water quality. Identifying optimal/ near optimal land use pattern using SWAT (Arnold et al., 1993, 1996), minimizing nutrient and sediment loads in watersheds by reduction of peak flow, preparing model for reduction of non-point pollutants before they enter into receiving water bodies (Yang et al., 1987), correlating water sediments (land erosion) with runoff flow in channels (Tripathi et al., 2003) and so on, are more associated with the prediction of runoff and simulation of its associated effects on the landscape, especially in the humid areas where saturation excess processes are more prevalent because of thin humid soils that

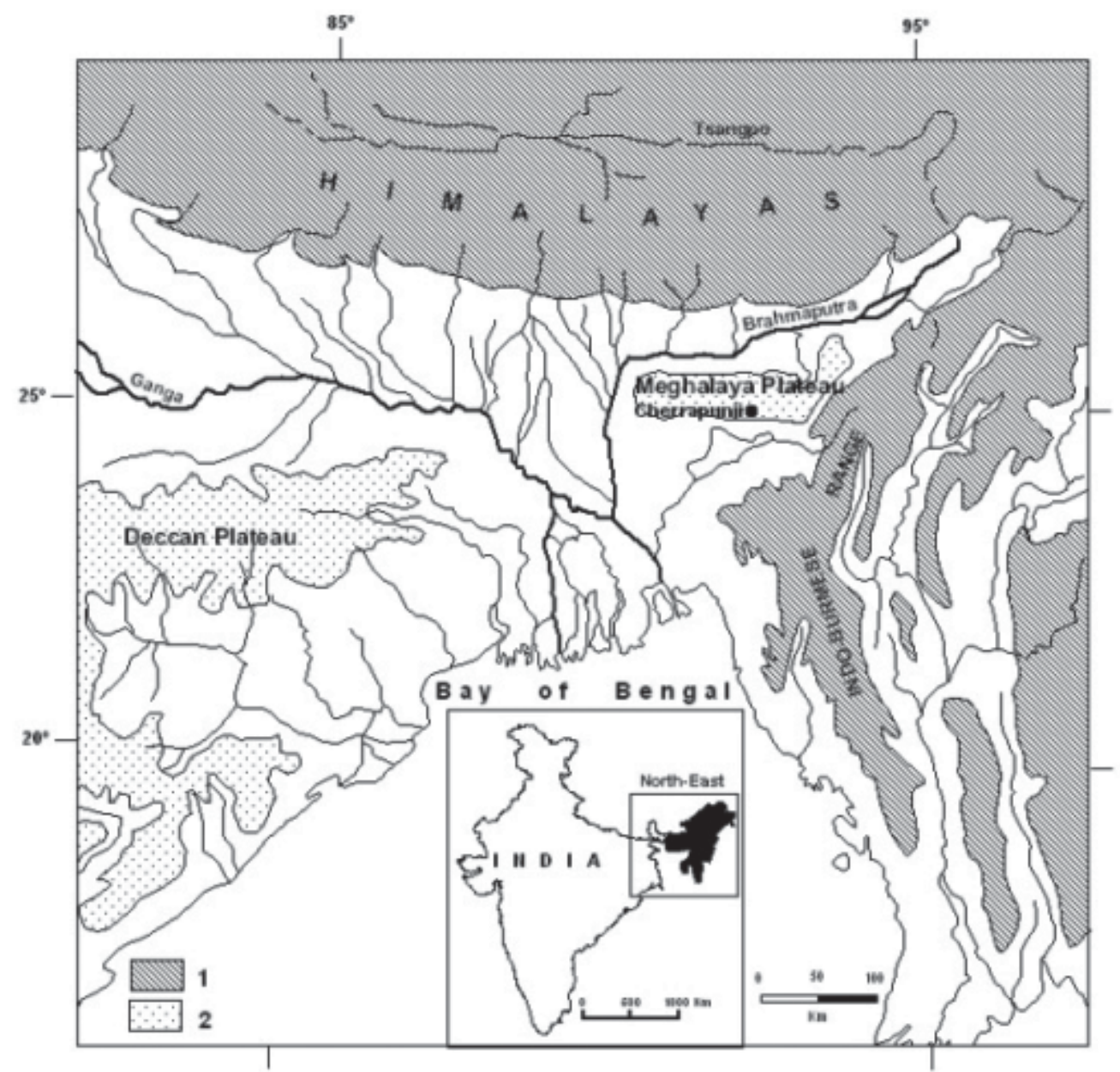

Figure 1. Situation of the Meghalaya Plateau in its regional surroundings (courtesy: Singh et al., 2010)

N. B.: 1 - areas above 1,600 m a.s.l., 2 - areas of 900 to 1,600 $\mathrm{m}$ a.s.l. 
increase sub-surface flow and exfiltration. Hence, the formulation of an appropriate model is to be pursued and applied considering the real world situation of the study area.

\section{STUDY AREA}

The Um-U-Lah watershed lies to the south of Cherrapunji, on the south-facing slope of the Meghalaya Plateau situated between the Bay of Bengal in the south and the Himalayas in the north (Fig. 1). This watershed is small in size, covers an area of only 103.4 ha, and extends from 91'42'54" to 91'43'46" East longitudes and $25^{\circ} 17^{\prime} 05^{\prime \prime}$ to $25^{\circ} 16^{\prime} 07^{\prime \prime}$ North latitudes. The Um-U-Lah watershed encompasses two localities of Cherrapunji (Sohra), namely: Maraikaphon and Khliehshnong. The watershed has an undulating topography which comprises small hills and depressions. The watershed is bounded by hillocks with an elevation range of 1,200-1,350 m a.s.l. Streams emanate from all sides of these hillocks and the watershed slope aspect faces south (Fig. 2).

A relative height of $130 \mathrm{~m}$ in the 1.70-km-long Um-U-Lah watershed (Cherrapunji) is observed. An average slope of about 8.0 percent has been noticed from an elevation of 1,310 $\mathrm{m}$ a.s.1 . (mouth of the watershed) to the upper reaches at 1,440 $\mathrm{m}$ a.s.l. Hill tops are generally flat and hill sides are dissected by streams (perennial and ephemeral). Two streams are perennial and others are seasonal, passing through the depressions during heavy-rainfall monsoon season. The area-elevation curve of the Um-U-Lah watershed shows proportionate distribution of area under each category of relative height of the watershed. The fractional areas under each relative height are almost equal in the Um-U-Lah watershed (Fig. 3A). In spite of the prevalence of moderate and moderately steep slopes (10-35\%) in most of the areas of the watershed (Fig. 3B), there is a significant variation in slope categories.
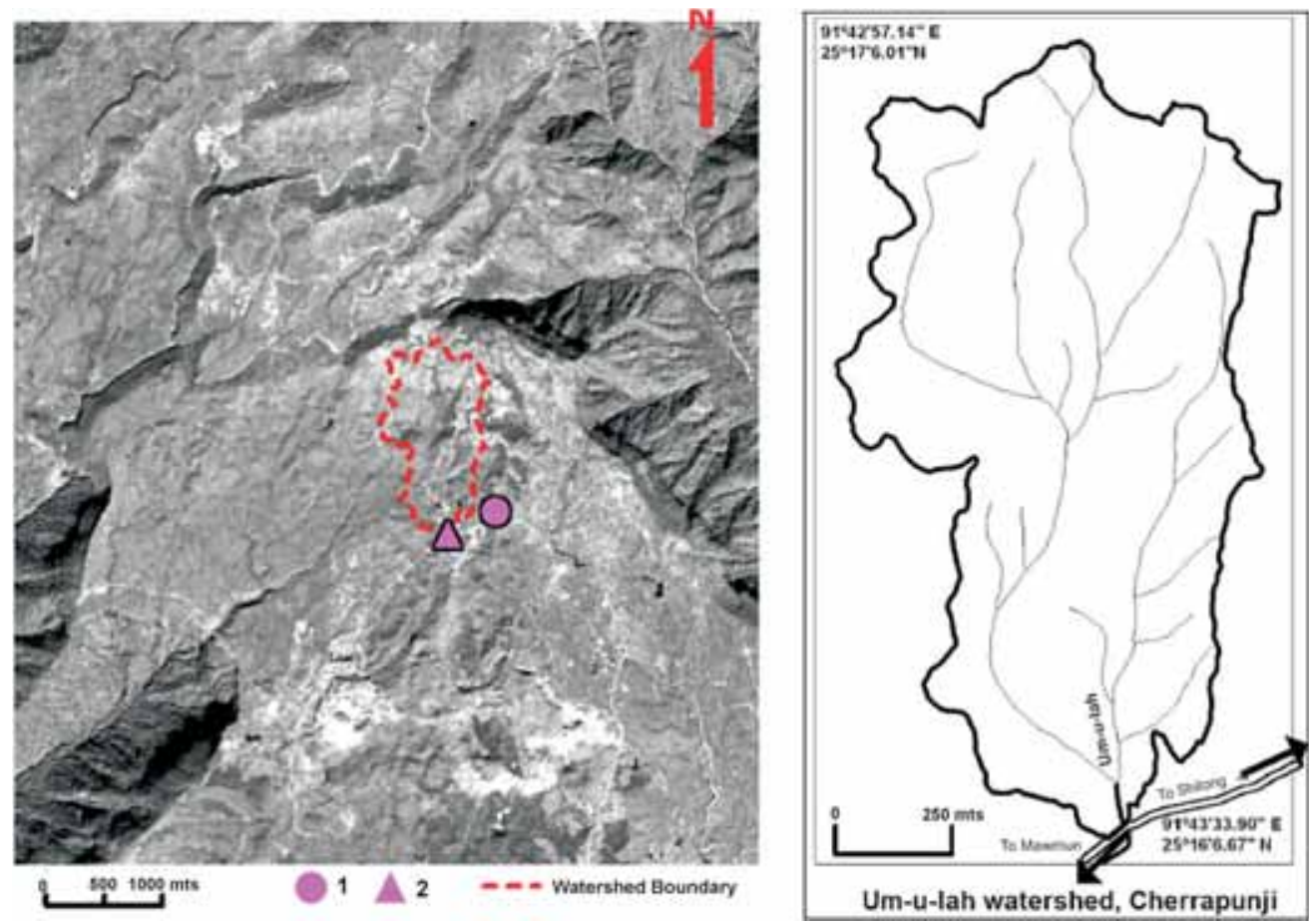

Figure 2. Location of the experimental watershed N.B. 1 - location of AWS, 2 - location of Water Level Recorder 
More than three-fourth area of the Um-U-Lah watershed accounts for slopes of moderate categories below 35\%, while steep slopes are found either near the mouth or

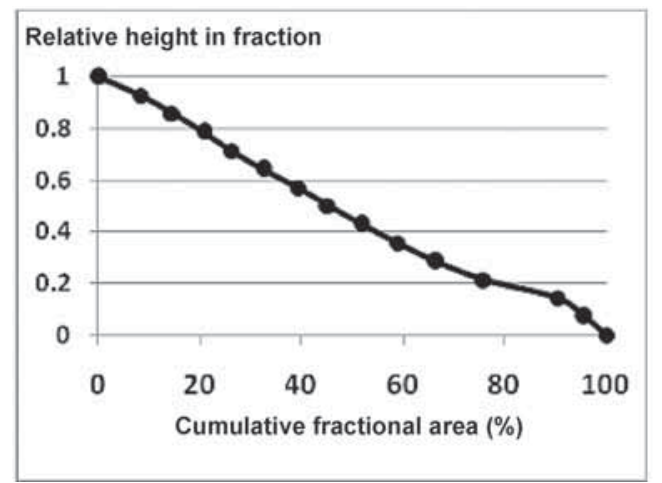

around the confluence points of streams in the watershed (Fig. 4A).

More than three-fourth of the Um-U-Lah watershed is dominated by tall grasses with

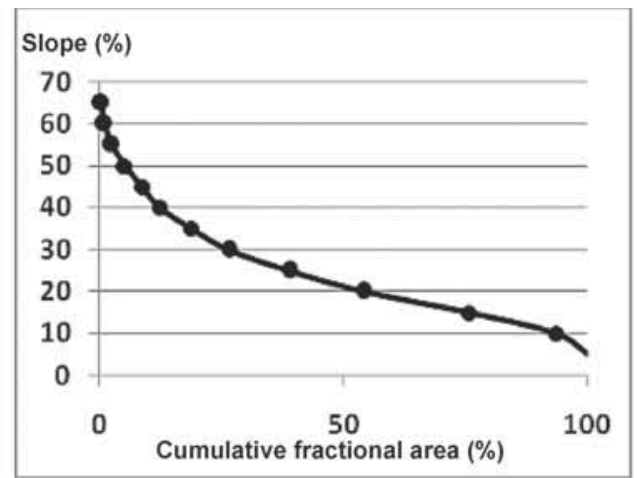

Figure 3. (A) Hypsometric curves and (B) area-slope curves for the Um-U-Lah watershed

A

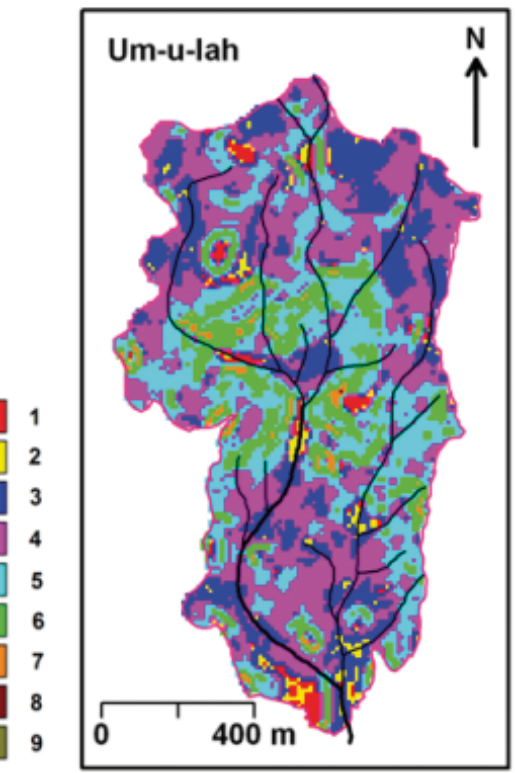

B

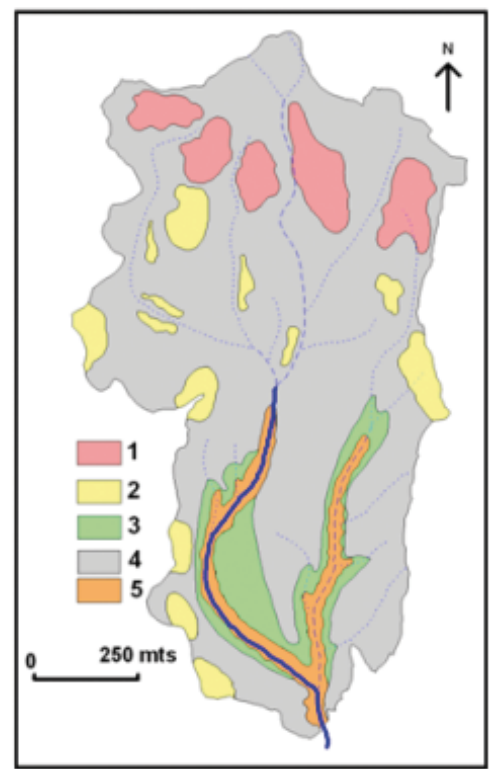

Figure 4. (A) Slope variations and (B) hydrological soil types in the experimental watershed

A. 1 - flat (below $-2 \%), 2$ - very gentle (2-4\%), 3 - gentle (4-10\%), 4 - moderate (10-20\%), 5 - moderately steep (20-35\%), 6 - steep (35-60\%), 7 - very steep (60-100\%), 8 - most steep (100-175\%), 9 - extremely steep (above 175\%); B. 1 - deep soil with less slope $\left(\mathrm{K}=70 \mathrm{~cm} \mathrm{day}^{-1}, \mathrm{~d}=100 \mathrm{~cm}, \mathrm{t}=7,000 \mathrm{~cm}^{2}\right.$ day $\left.^{-1}\right) ; 2$ - thick with stony edge surface $\left(\mathrm{K}=90 \mathrm{~cm} \mathrm{day}^{-1}, \mathrm{~d}=60 \mathrm{~cm}, \mathrm{t}=5,400 \mathrm{~cm}^{2} \mathrm{day}^{-1}\right) ; 3$ - shallow but highly porous gravelly sand $\left(\mathrm{K}=100 \mathrm{~cm} \mathrm{day}^{-1}, \mathrm{~d}=50 \mathrm{~cm}\right.$, $\mathrm{t}=500 \mathrm{~cm}^{2}$ day $\left.^{-1}\right) ; 4$ - shallow soil with grass dominance $\left(\mathrm{K}=100 \mathrm{~cm}_{\text {day }}{ }^{-1}, \mathrm{~d}=60 \mathrm{~cm}, \mathrm{t}=600 \mathrm{~cm}^{2}\right.$ day $\left.{ }^{-1}\right) ; 5$ - very shallow with rocky exposed $\left(\mathrm{K}=100 \mathrm{~cm}\right.$ day-1, $\mathrm{d}=30 \mathrm{~cm}, \mathrm{t}=300 \mathrm{~cm}^{2}$ day $\left.^{-1}\right) ; \mathrm{K}-$ saturated conductivity, $\mathrm{d}=$ soil depth and $\mathrm{t}=$ soil transimissivity $\left(\mathrm{t}=\mathrm{K}^{*} \mathrm{~d}\right)$ 
heights of about $20 \mathrm{~cm}$ to $100 \mathrm{~cm}$, possessing linear leaves measuring about $10-65 \mathrm{~cm}$ wide. Such grasses belong to Poaceal family with fibrous root system (Chakraborty et al., 2009; Kumar and Syiemlieh, 2010: pp. 6970 ), forming a thick netting that restricts to surface within the $5-10 \mathrm{~cm}$ on the top soils (Uma Shankar et al., 1991). It creates a degree of macro-porosity and consequently increases infiltration rate in the area. The forest patches are limited and situated on the upper part of watershed and along valley slopes. Thus, there is not much spatial variability in the land use/ land cover pattern since the watershed is very small (Table 1).

Table 1. Land use/land cover of experimental watershed

\begin{tabular}{lcc}
\hline \multirow{2}{*}{ Land use categories } & \multicolumn{2}{l}{ Total area } \\
\cline { 2 - 3 } & ha & $\%$ \\
\hline Forest & 16.85 & 16.30 \\
Grassland & 78.12 & 75.55 \\
Barren land (exposed rocks) & 0.88 & 0.85 \\
Settlements and Roads & 7.48 & 7.23 \\
Ponds & 0.07 & 0.07 \\
\hline
\end{tabular}

Source : Area figures of different categories were generated by using satellite imageries of Cartosat-II at spatial resolution of $2.5 \mathrm{~m}$.

In general, the soils of the surrounding areas of Cherrapunji where Um-U-Lah wa- tershed is located are classified as Humic Dystrudepts/Typic Kanhaplohmults under the world soil taxonomy, exhibiting sandy loam and loamy texture (NBSS\&LUP, 1996). The surface soils are low in clay content, highly porous and shallow $(40 \mathrm{~cm}$ to 80 $\mathrm{cm}$ ) in depth, comprising gravelly material (coarse fragments above $2.0 \mathrm{~mm}$ ) and have a sandstone bedrock (Prokop, 2010). In the inner layers of the soil, the coarse sand accounts for more than 50 percent share in soil texture. As a result, bulk density is found to be low $\left(1.4 \mathrm{~g} \mathrm{~m}^{-3}\right)$ with very high infiltration capacity (more than $100 \mathrm{~cm} /$ day) influencing the lateral flow contribution to hydrographs. Largely, the soils of this watershed possess this character (Fig. 4B). Macro-porosity agents, like tree-root nets, cracks in surface soils and borrowing organisms also add to the effects in increasing infiltration capacity. However, during the rainy summers, infiltration capacity is negligible due excessive saturation arising out of thin soil cover.

Undulating topography, spatially variable slopes and shallow soils with low infiltration capacity associated with large volume precipitation enhance runoff depth as well as runoff ratio. The months of June, July and August are extremely humid and receive more than three-fourth share of the total annual rainfall (Fig. 5).

The rainfall observations are based on data collected from Automatic Weather Station. The total rainfall in this seasonal dis-

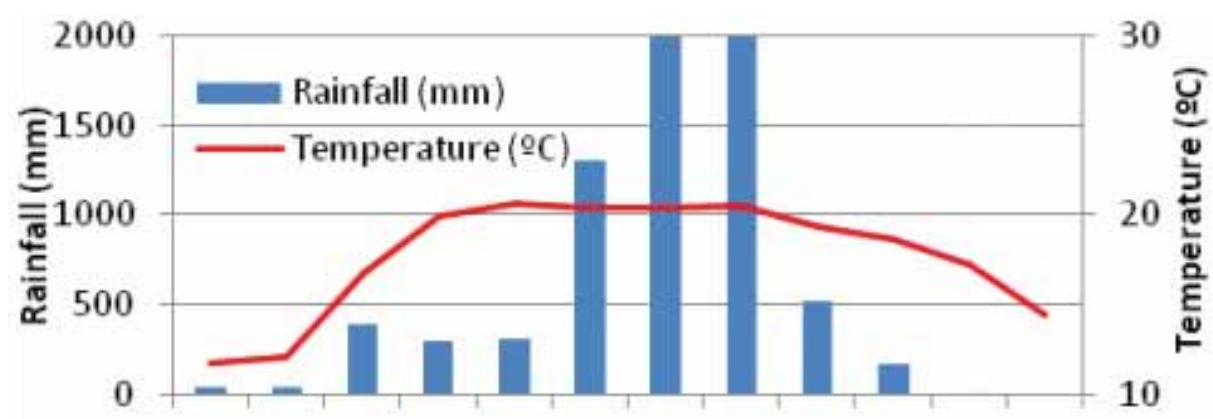

Jan Feb Mar Apr May June July Aug Sept Oct Nov Dec Months

Figure 5. Monthly rainfall and temperature at Cherrapunji (2008) 
Table 2. Hydrologic characteristics of an event of 12-hours in Um-U-Lah watershed

\begin{tabular}{|c|c|}
\hline Description & Um-U-Lah Watershed \\
\hline Size of watershed (ha) & 103.40 \\
\hline Antecedent moisture conditions (AMC) & III \\
\hline Hydrologic event duration (hours) & 12.00 \\
\hline Total surface water $(\mathrm{RO})$ produced $\left(\mathrm{m}^{3}\right)$ & 279865.10 \\
\hline Average surface water produced $\left(\mathrm{m}^{3} \mathrm{~h}^{-1}\right)$ & 23322.10 \\
\hline Average surface water yield produce $\left(\mathrm{m}^{3} \mathrm{~h}^{-1} \mathrm{ha}^{-1}\right)$ & 225.55 \\
\hline Total storage in channels $\left(\mathrm{m}^{3}\right)$ & 20486.10 \\
\hline Share of storage of total volume per $\mathrm{cm}$ of Pnet (\%) & 7.32 \\
\hline Total precipitation $(\mathrm{mm})$ & 262.80 \\
\hline Total loss (mm) & 10.80 \\
\hline Share of loss to total (\%) & 4.15 \\
\hline $\mathrm{P}$ net $(\mathrm{P}-\mathrm{loss})=(\Sigma \mathrm{Qdt} / \mathrm{A})(\mathrm{mm})$ & 252.00 \\
\hline Travel time (hrs) & 1.00 \\
\hline Peak flow $\left(\mathrm{m}^{3} \mathrm{~s}^{-1}\right)$ & 11.21 \\
\hline Average discharge $\left(\mathrm{m}^{3} \mathrm{~s}^{-1}\right)$ & 6.47 \\
\hline Minimum discharge $\left(\mathrm{m}^{3} \mathrm{~s}^{-1}\right)$ & 2.90 \\
\hline Standard Deviation of discharge $\left(\mathrm{m}^{3} \mathrm{~s}^{-1}\right)$ & 2.91 \\
\hline Co-efficient of variation of discharge $(\%)$ & 44.95 \\
\hline
\end{tabular}

tribution is counted at about $7,000 \mathrm{~mm}$, i.e., less than the normal annual mean because of the non-availability of observations, especially October to December 2008

From a much more intense part of a rainstorm, a 12 hours duration hydrograph (4:00 to $15: 00$ on $18^{\text {th }}$ July 2007$)$, depicting a total rainfall of $262.8 \mathrm{~mm}$ with an average rainfall intensity of $21.9 \mathrm{~mm} / \mathrm{h}$ ), a negligible precipitation loss was observed, i.e., only $3.00 \mathrm{~mm}$ (about $1.15 \%$ to total rainfall precipitated during the hydrologic event). It means that much less rain water was absorbed by the soil since the Antecedent Moisture Condition (AMC) was already excessive (Table 2).

In such an extreme wet condition of landscape with less water holding capacity of shallow soils and high degree of macro-porosity, the highly undulating landscape and variable slope characteristics are suitable to test the validity of saturation excess method that is based on the Topographic Wetness Index (TWI) for accurate location and determination of the extent of saturated areas within the watershed. This is associated with the Variable Source Area (VSA) modelling system. The impact assessment of topography and soil (while land use/land cover is assumed homogenous as it does not vary much spatially) on the amount and intensity of runoff in the watershed asserts a major methodological issue. In the present paper, attention is thus focused towards the prediction of runoff through the use of saturation excess processes that are operating in such specific conditions of landscape.

\section{METHODS AND DATA COLLECTION}

The location and extent of saturation excess areas are greatly dependent on two parameters of runoff generation. First, the saturated incremental fraction contributing to the runoff depth (Af) that is an extension 
of SCS-CN method (USDA..... 1972; Steenhius et al., 1995) is represented as:

$\mathrm{Q}=\left[(\mathrm{P}-\mathrm{Ia})^{2} /(\mathrm{P}+\mathrm{S}-\mathrm{Ia})\right]$

when $\mathrm{P} \geq \mathrm{Ia}$; otherwise $\mathrm{Q}=0$ when $\mathrm{P} \leq \mathrm{Ia}$,

where $\mathrm{Q}$ is the depth of direct runoff, $\mathrm{P}$ is rainfall, $\mathrm{S}$ is amount of water storage available in the soil profile or the maximum storage, and Ia is initial abstraction, so the effective rainfall is defined by $\mathrm{Pe}=\mathrm{P}-\mathrm{Ia}$ and effective available storage, $\mathrm{Se}=\mathrm{S}-\mathrm{Ia}$. The differential of the above equation with respect to effective rainfall, that indicates the saturated incremental fraction to runoff depth, becomes:

$\mathrm{Af}=\mathrm{dQ} / \mathrm{dPe}=1-\left[\mathrm{S}^{2} /(\mathrm{Pe}+\mathrm{S})^{2}\right]$.

Secondly, TWI will determine the areas of relative propensities for saturation within the watershed (Lyon et al., 2004). TWI is the logarithmic function of (i) the runoff contributing area per unit of contour length ( $\alpha$ in $\mathrm{m}^{2} / \mathrm{m}$, that is $\mathrm{m}$ units) and is the negative function of (ii) the slope gradient (tan $\beta$ in $\mathrm{m} / \mathrm{m}$ ), (iii) the hydraulic conductivity of saturated soil ( $\mathrm{k}$ in $\mathrm{cm} /$ day), and (iv) the soil depth $(\mathrm{d}$ in $\mathrm{cm}$ ) that has been formulated by Beven and Kirkby (1979) and computed by Lyon et al. (2006) as:

$\operatorname{TWI}(\lambda)=\ln \left[\left(\alpha /\left(\tan \beta * k^{*} d\right)\right]\right.$.
The first parameter of runoff generation, that is rainfall, is considered as homogenous as the effective rainfall $(\mathrm{Pe})$ is assumed uniformly distributed in the watershed because of its very small size, while TWI spatially varies. It is to be mapped. In the present case, grid cells of $10 \mathrm{~m} \times 10 \mathrm{~m}$ size were considered for the Um-U-Lah watershed for the preparation of TWI map. A digital elevation model (DEM) was used to map surface gradient of the watershed. The determination of $\lambda$ value for each grid cell was carried out in a GIS environment (ILWIS), including further processing of concerned spatial data for the purpose of mapping (Fig. 6).

Since $\lambda$ is dependent on the contributing area of flow direction and flow accumulation parameters of topography, the grid cell frequency of each $\lambda$ class is multiplied with its areal size to show the contributing area (Ac) of respective wetness classes, which has finally been converted into its fractional form (Ac/A) for further analysis (Fig. 7). Identification of the location of saturated area (As) is based on an assumption that saturated fraction of runoff depth equals to fractional contributing area, $(\mathrm{Af}=\mathrm{Ac} / \mathrm{A})$, which provides a critical value of $\lambda$ to classify saturated grid cells and to locate saturated areas in the watershed. Higher is the value of $\lambda$ and, consequently, lesser is the extent of saturated area and vice versa.

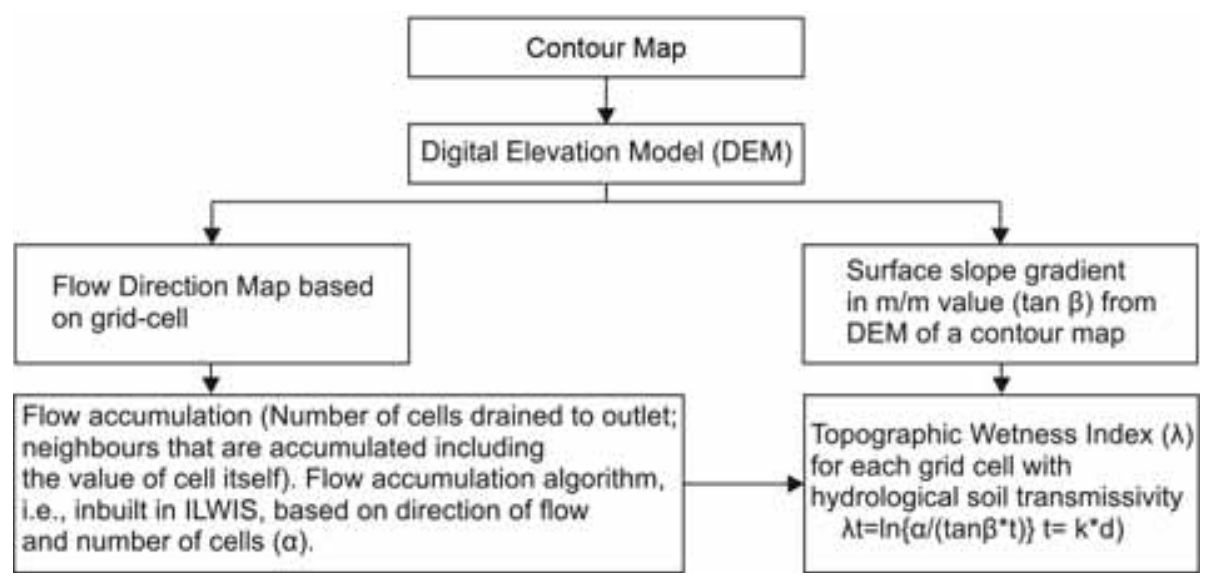

Figure 6. Development of the Topographic Wetness Index $(\lambda)$ for estimating effects of topographic factors on runoff in watershed (Beven and Kirkby, 1979) 
A

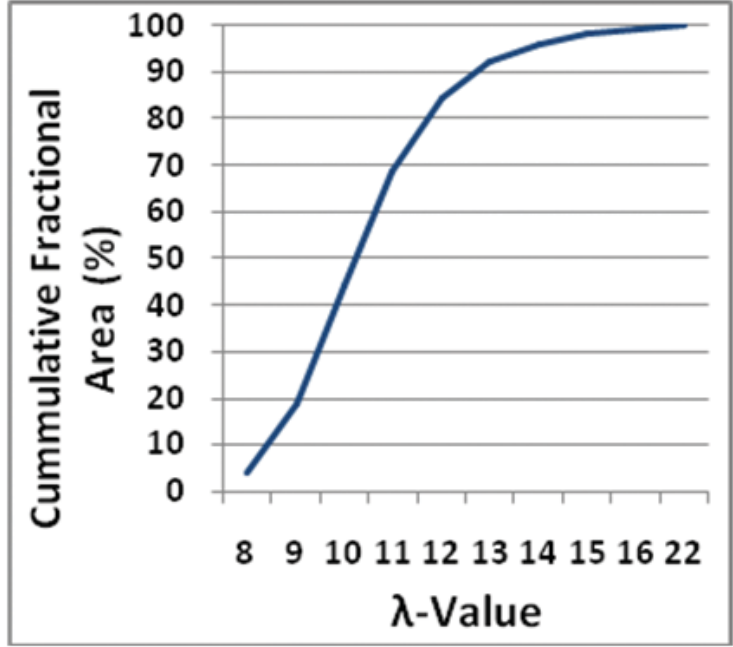

B

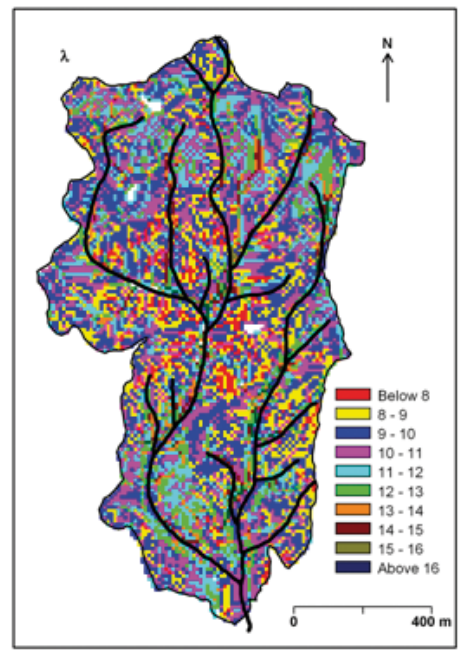

Figure 7. (A) Ogive based on TWI with different hydrological soil conditions and (B) distribution of TWI

It is to be noted here that since the intensity of effective rainfall $(\mathrm{Pe})$ varies over time, the location of saturated areas contract or expand repeatedly; these areas are variable over a constant wetness index-map because each grid-cell of the watershed shows a relative propensity of becoming saturated and producing saturation excess runoff. The runoff depth of each cell $(q)$ is, therefore:

$\mathrm{q}=\mathrm{Pe}-\mathrm{Se}$ when $\mathrm{Pe}>\mathrm{Se}$,

otherwise $\mathrm{q}=0$.

A total quantity of discharge $(\mathrm{Q})$ is then the multiplication factor between runoff depth and area of saturated cells as

$\mathrm{Q}=\sum\left(\mathrm{q}_{\mathrm{i}}^{*} \mathrm{ac}_{\mathrm{i}}\right)$,

$\mathrm{i}=1,2,3, \ldots, \mathrm{n}$ cells falling within saturated area.

\section{CALIBRATION AND VALIDATION OF THE MODEL}

Rainfall simulations were conducted to calibrate the Curve Number based VSA-model at $\mathrm{Se}=5.88 \mathrm{~mm}$ and Ia (initial abstraction) was taken at $1.746 \mathrm{~mm}$ for the Um-U-Lah watershed. These values were calculated by using the Thornthwaite and Mather's (1957) (T-M) procedure of soil water availability in water balance sheet for AMC-III as wet soil conditions. Simulations were made to consider natural soil conditions $(\lambda)$. The input of the model is the effective rainfall depth, which varies at intervals of $2.0 \mathrm{~mm}$ within the range from 0 to $25 \mathrm{~mm}$ to visualize the changes in the wetness index $(\lambda)$ and accordingly the location and extent of saturated areas within the watershed. Validation of the model was done by using the Coefficient of Efficiency (E) given by Nash and Sutchiffe (1970), as it is based on the following equation:

$\mathrm{E}=1-\left[\sum(\mathrm{Qo}-\mathrm{Qp})^{2} / \sum\left(\mathrm{Qo}-\mathrm{Qo}_{\text {mean }}\right)^{2}\right]$.

If $\mathrm{E}=1.00$, it shows perfect agreement between observed Qo and predicted Qp values. Increasing unexplained variation that may arise will decrease the coefficient value of efficiency of the model. Validity testing was done on the extreme event of 12 hours starting from 4:00 hr $18^{\text {th }}$ July 2007 in the Um-U-Lah watershed, with a total rainfall of $262.8 \mathrm{~mm}$ (an average intensity of $21.99 \mathrm{~mm}$ $\mathrm{h}^{-1}$ ). The effect of concentration time was 
not considered in the use of present model because the model is tested in micro-areal watershed of 103 ha of its size.

\section{RESULTS AND DISCUSSION}

Interpretation of output map produced by the wetness index $(\lambda)$ provides certain clues as to the location and extent of saturated areas. It is obvious from Table 3 that the first four categories of the wetness index from extremely wet to wet (below 11.0 value of wetness index) include more than two-third areas of the watershed, which indicate probability to produce more runoff. The location of such areas of wet soil conditions are observed mostly either in the flat hill tops in the central part or near the mouth of watershed where low-transmissibility shallow and highly porous gravelly soils are prevalent (Fig. 8). After visualizing the pattern of the wetness index, it may be characterized as 'normally distributed' at its mean value of 10.6, with low coefficient of spatial variability $(\mathrm{CV}=17.11 \%)$ coupled with moderate degree of deviations in kurtosis and skewness (Table 4).

Table 3. Percentage share of contributing areas of various wetness classes in Um-U-Lah watershed

\begin{tabular}{lrr}
\hline \multirow{2}{*}{ Wetness class ( $\lambda$ value) } & \multicolumn{2}{l}{ Total area } \\
\cline { 2 - 3 } & ha & \multicolumn{1}{c}{$\%$} \\
\hline Extremely wet (Below 8) & 3.94 & 3.83 \\
Very wet (8 to 9) & 14.97 & 14.77 \\
Moderately wet (9 to 10) & 25.88 & 25.58 \\
Wet (10 to 11) & 24.67 & 24.47 \\
Dry (11 to 12) & 15.97 & 15.78 \\
Moderately dry (12 to 13) & 8.59 & 7.87 \\
Very dry (13 to 14) & 3.99 & 3.69 \\
very very dry (14 to 15) & 2.57 & 2.17 \\
Extremely dry (15 to 16) & 1.19 & 0.95 \\
Driest (Above 16) & 1.09 & 0.89 \\
\hline
\end{tabular}

N.B.: Lower values of grid-cells indicate more wet and vice-versa
Table 4. Characteristics of wetness distribution in Um-U-Lah watershed

\begin{tabular}{lr}
\hline Wetness Index $(\lambda)$ & \\
\hline No. of Cells & 10166.00 \\
Minimum & 7.10 \\
Maximum & 19.34 \\
Mean & 10.60 \\
Range* & 12.24 \\
Standard Deviation & 1.81 \\
Coefficient Variation & 17.11 \\
Kurtosis & 1.35 \\
Skewness & 0.91 \\
\hline
\end{tabular}

N. B.: *range is calculated subtracting minimum values from maximum ones

In such moist wet soil conditions, increasing depth of effective rainfall results in a fast increase in the extent of saturated areas. The saturated area was observed to be only 6.58 percent when effective rainfall was $1.00 \mathrm{~mm}$. The saturated area increased to 47.17 percent when effective rainfall is increased by $3.00 \mathrm{~mm}$. Accumulation of water in the flat lands of the central part of the watershed contributed to saturated areas. Such areas are increased to 67.49 percent $(20 \%$ additional areas including flat tops of hills and settlement areas) when the depth of Pe is increased by $2.00 \mathrm{~mm}$, i.e., from 3.00 to $5.00 \mathrm{~mm}$. Likewise, 81.0 percent of the areas become saturated at a depth of $9.00 \mathrm{~mm}$ of effective rainfall (Fig. 8, Table 5).

In general, it can be concluded that effective rainfall expands saturated areas within the watershed faster in the Um-U-Lah watershed located in the extreme wet conditions (Cherrapunji) and, as a result, the watershed produces much more runoff with higher runoff ratio.

Calculating the location and extent of saturated area for the observed hourly rainfall of this event and finally predicting runoff depth, it is found that there is significant agreement of observed and predicted values of runoff. In a later period of the event, it was found that the model overestimated 


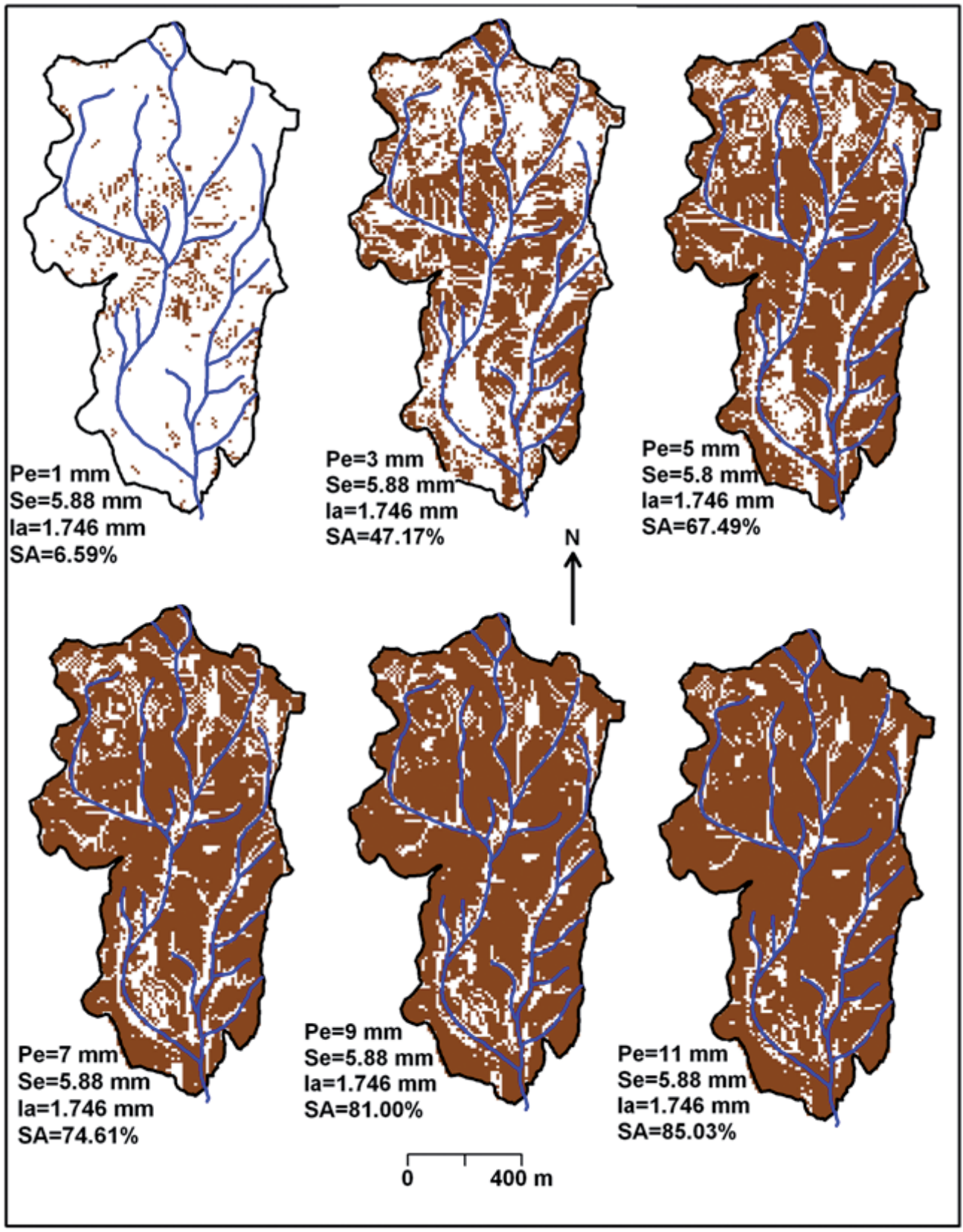

Figure 8. Patterns of saturated areas at different effective rainfall intensities

runoff. This may have happened because of non-inclusion of the effect of concentration time (i.e., considered 1:00 hour) for this watershed. The Nash and Sutchiffe's coef- ficient of efficiency is calculated at .65716 with standard error of $5.68 \mathrm{~mm}$. After this was incorporated, it shows good agreement of these two distributions of runoff (Fig. 9). 
Table 5. Simulation of saturated areas in Um-U-Lah watershed (at $\mathrm{Ia}=1.746 \mathrm{~mm}, \mathrm{Se}=5.88 \mathrm{~mm}$ )

\begin{tabular}{ccllcll}
\hline Rainfall & Pe & Af $(\mathrm{mm})$ & $\lambda$-value & No. of cells & Saturated Area (ha) & Saturated Fractional Area \\
\hline 1.764 & 0 & 0 & 0 & 0 & 0 & 0 \\
2.764 & 1 & 0.269571 & 9.35 & 681 & 6.81 & 0.065860735 \\
4.764 & 3 & 0.561541 & 10.45 & 4878 & 48.78 & 0.471760155 \\
6.764 & 5 & 0.707923 & 11.1 & 6979 & 69.79 & 0.674951644 \\
8.764 & 7 & 0.791588 & 11.65 & 7715 & 77.15 & 0.746131528 \\
10.764 & 9 & 0.843848 & 11.95 & 8376 & 83.76 & 0.810058027 \\
12.764 & 11 & 0.878658 & 12.25 & 8793 & 87.93 & 0.850386847 \\
14.764 & 13 & 0.903005 & 12.6 & 9146 & 91.46 & 0.884526112 \\
16.764 & 15 & 0.920696 & 12.95 & 9355 & 93.55 & 0.904738878 \\
18.764 & 17 & 0.933955 & 13.2 & 9495 & 94.95 & 0.91827853 \\
20.764 & 19 & 0.944146 & 13.3 & 9533 & 95.33 & 0.921953578 \\
22.764 & 21 & 0.952148 & 13.4 & 9564 & 95.64 & 0.924951644 \\
24.764 & 23 & 0.958547 & 13.6 & 9631 & 96.31 & 0.931431335 \\
26.764 & 25 & 0.963742 & 13.8 & 9690 & 96.9 & 0.937137331 \\
\hline
\end{tabular}

A

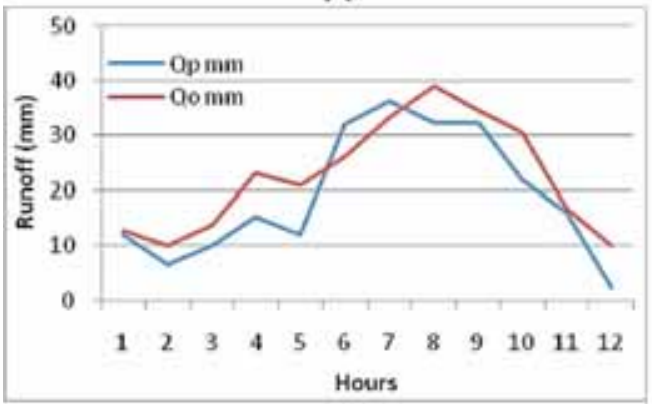

B

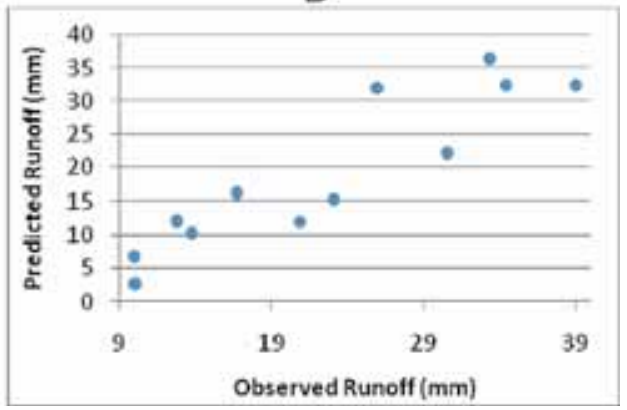

Figure 9. Um-U-Lah watershed: (A) trends of predicted and observed runoff, and (B) scatter between predicted and observed runoff

\section{MAIN FINDINGS}

(1) There are a few generalizations based on the model analysis that show clearly the complete agreement of rainfall and runoff curves during the hydrologic events with its high fluctuations and very high average runoff yield in the Um-U-Lah watershed (Cherrapunji), located in extremely high rainfall areas. For example, an average water yield of $225.5 \mathrm{~m}^{3}$ per hour per ha was calculated from the Um-U-Lah watershed of 103.4 ha dur- ing an extreme event of $262 \mathrm{~mm}$ of rainfall precipitated in 12 hours with wet AMC. This average yield is incomparable even with the runoff yield of the other humid tropic areas of the world.

(2) The 'S' type of ogive of wetness index distribution has fast rising nature in wet soils prevalent in the Cherrapunji area of extremely humid conditions. It means that increasing depth as well as porosity of soils limits the saturation areas in the watershed and, consequently, checks the discharge rate 
of runoff at the mouth of the watershed. Such soil parameters also have impact of spatial processes of saturation in the watershed. The shallow soil of the Um-U-Lah watershed in extreme wet conditions has faster rate of filling up the storage deficit leading to quicker saturation of soils and thereby saturated areas expand faster. Consequently, more areas may be saturated even at a low depth of effective rainfall in a thin soil cover. In such conditions, the runoff ratio increases fast and contributes to direct runoff.

(3) Considering natural condition of soils of the experimental watershed, and calibrating VSA-CN Model at effective soil moisture level at $\mathrm{Se}=5.88 \mathrm{~mm}$ for the Um-U-Lah watershed as calculated by using the T-M procedure of water budget balance equation for wet weather condition as prevalent in the watershed during experiments, the location and extent of saturation areas vary at different effective rainfall depth in the following manner:

a) Increasing depth of effective rainfall quickly expands the saturated areas in the Um-U-Lah watershed. At $8.25 \mathrm{~mm}$ of effective rainfall depth, about 85.03 percent area of the watershed becomes saturated. In contrast, the areas of watershed having highly porous deep soil with more saturation capacity have less fractional areas under saturation.

b) The distribution of contributing areas to the wetness index follows the trend of normal distribution in all topographic and soil conditions. However, the steepness of cumulative distribution (ogive) of TWI varies for different relief and soil conditions.

c) Saturated areas are controlled by the surface gradient. Saturation starts initially at the flat hill-tops and then expands towards low slope areas within the watershed. Therefore, the surface gradient has a negative impact on saturation processes.

Finally, it can be concluded that the location and extent of saturation areas, which are greatly related to the prediction of runoff within the watershed, are directly influenced by the expansion of accumulating water location, and inversely related to the surface gradient as well as soil transmissibility. Such factors of topography limit the wetness index and saturation processes in the watershed.

\section{ACKNOWLEDGEMENTS}

The task of selecting the appropriate sites for the experimental watershed was pursued in consultation with the Scientists of the Department of Geomorphology and Hydrology of Mountains and Uplands, Kraków (Poland), Institute of Geography and Spatial Organization, Polish Academy of Sciences, which conducts an Inter-governmental Research Program with our University. We are also thankful to the Department of Science and Technology (DST), New Delhi, for providing financial help in setting up of hydrological observatory under the Natural Resource Data Management System (NRDMS) Project (Grant No. ES/11/833/2004).

\section{REFERENCES}

Arnold, J.G., Allen, P.M. and Bernhardt, G. (1993), A Comprehensive Surface-Groundwater Flow Model, Journal of Hydrology, 142: 47-69.

Arnold, J.G., Williams, J.R., Srinivasan, R. and King, K.W. (1996), Soil and Water Assessment Tools, Users' Manual, USDA, Agriculture Research Services, Soil and Water Research Laboratory, Temple, USA.

Beven, K.J. and Kirkby, M.J. (1979), A physically based variable contributing area model of basin hydrology, Hydrology Science Bulletin, 24: 43-69.

Chakraborty, K., Joshi, P.K. and Sarma, K.K. (2009), Land use/ land cover dynamics in Umnogt watershed of Meghalaya using Geospatial Tools, Journal of the Indian Society of Remote Sensing, 37(1): 99-106.

Frankenberger, J.R., Brooks, E.S., Walter, M.T., Walter, M.F. and Steenhuis, T.S. (1999), A GIS-based variable source area hydrology model, Hydrological Processes, 13:805-822. 
Kumar, Y. and Syiemlieh, H.J. (2010), Vegetation and plant communities, in Singh, S., Starkel, L. and Syiemlieh, H.J. (eds.), Land Degradation and Ecorestoration in the Extremely Wet Monsoon Environment of Cherrapunji Area, India, Bookwell Publications, New Delhi, 69-73.

Lyon, S.W., Seibert, J., Lembo, A.J., Walter, M.T. and Steenhuis, T.S. (2006), Geostatistical investigation into the temporal evaluation of spatial structure in a shallow water table, Hydrology and Earth System Sciences, 10: 113-125.

Lyon, S.W., Walter, T., Grand Marchant, P. and Steenhuis, T.S. (2004), Using a topographic index to distribute variable source area runoff predicted with the SCS curve-number equation, Hydrological Processes, 18: 2757-2771.

Mishra, S.K, Sarkar, R., Dutta, S. and Panigrahy, S. (2008), A physically hydrological model for paddy agriculture dominated hill watershed in tropical region, Journal of Hydrology, 357: 389-404.

Nash, J.E. and Sutcliffe, J.V. (1970), River flow forecasting through conceptual model: Part-I A Discussion of principles, Journal of Hydrology (Amsterdam), 10 (3): 282-290.

NBSS\&LUP (1996), Soil map of Meghalaya, National Bureau of Soil Survey and Land Use Planning, Government of India, Nagpur.

Prokop, P. (2010), Soil resources and soil degradation, in Singh, S., Starkel, L. and Syiemlieh, H.J. (eds.), Land degradation and ecorestoration in the extremely wet monsoon environment of Cherrapunji area, India, Bookwell Publications, New Delhi, 61-68.

Singh, S., Starkel, L. and Syiemlieh, H.J. (eds.) (2010), Land degradation and ecorestoration in the extremely wet monsoon environment of Cherrapunji area, India, Bookwell Publications, New Delhi.

Singh, S. and Syiemlieh, H.J. (2010), Runoff process in extremely humid areas of the Central Meghalaya Plateau, Research Monograph No: GE/NRDMS/DST/SS/10, Department of Geography, North Eastern Hill University, Shillong.
SMDR (2003), Soil moisture distribution and routing, Documentation (version 2.0), Soil and Water Laboratory, Biological and Environmental Engineering Department, Cornell University, Ithaca.

Steenhuis, T.S., Winchell, M., Rossing, J., Zallives, J.A. and Walter, M.F. (1995), SCS runoff equation revisited for variable source runoff area, Journal of Irrigation and Drainage Engineering, ASCE, 121(3): 235-238.

Thornthwaite, C.W. and Mather, J.R. (1957), Instructions and tables for computing potential evapotranspiration and water balance, Publications in Climatology, Vol. X (3), Drexel Institute of Technology, Centertown, New Jersey.

Tripathi, M.P., Panda, R.K. and Raghuwanshi, N.S. (2003), Calibration and validation of SWAT models for predicting runoff and sediment yield of a small watershed in India, International Agriculture Engineering Journal, 12(1-2): 95-118.

Uma Shanker, Tripathi, R.S. and Pandey, H.N. (1991), Structure and seasonal dynamics of humid tropical grasslands in Meghalaya, India, Journal of Vegetation Science, 18 (3): 395-406.

US Department of Agriculture, Soil Conservation Service (1972), Hydrology, in: SCS - National Engineering Hand Book, Washington DC, U S Department of Agriculture, Section 4.

Ward, R.C. (1984), On the response to prediction of head water streams in humid areas, Journal of Hydrology, 74: 171-189.

Yang, R.A., Onstad, C.A., Bosch, D.D. and Anderson, W.P. (1987), AGNPS: Agriculture Non-Point-Source Pollution Model - A Watershed Analysis Tool, US Department of Agriculture, Agriculture Research Services, Conservation Research Report 35, Beltsville, M.D.

Paper first received: April 2011

In final form: August 2011 
http://rcin.org.pl 